\title{
"What no eye has seen": Using a digital microscope to edit papyrus fragments of early Christian apocryphal writings
}

\author{
Brent Landau, Adeline Harrington and James $C$. Henriques
}

Scholars working with ancient papyri are often confronted with manuscripts that are challenging to read. Aside from the basic fact that papyri are often preserved in fragmentary condition, the deciphering of letters in the portions that remain frequently presents challenges. Sometimes only small parts of letters are preserved; at other times the ink may have faded away to near invisibility; and at still other times the letters are rendered almost unrecognizable by blotches of ink. Papyri may also be covered with an obscuring layer of silt as the result of inadequate conservation or a lack of conservation altogether, leaving scholars unclear as to what is ink and what is dirt. Faced with such challenges, editors still labor valiantly to produce accurate transcriptions of ancient texts. Nevertheless, uncertainties in readings still remain, and texts that have been edited more than once will sometimes have very different transcriptions. The difficulties in deciding which readings to prefer may even lead to the conclusion that such decisions are hopelessly arbitrary.

A relatively new technology, however, may be able to resolve some of these papyrological impasses, at least in part: digital microscopes. Although some of the leading repositories of papyri collections have had analog microscopes available for use by researchers for some time, digital microscopes have three significant advantages over analog microscopes. First, a digital microscope can be connected to a computer via a Us B port, allowing for the image to be seen on a computer screen, rather than straining through a tiny eyehole. Second, a digital microscope can take photographs of the manuscript under magnification, allowing an editor to provide key photographic evidence in favor of one reading over another - and this paper will include a selection of photographs taken with a digital microscope. Third, some digital microscopes - including the one used by the authors - have the added feature of ultraviolet and infrared lighting modes, and these different light spectra can greatly improve the legibility of ink in some cases. 
In publishing a paper devoted specifically to the application of a digital microscope to ancient manuscripts, the authors hope that this will encourage more scholars in this subfield to utilize this tool. We are not the first specialists in early Judaism and Christianity to use a digital microscope, however. By means of some informal crowd-sourcing on Facebook, the lead author determined that a small number of scholars in biblical studies and cognate fields started using digital microscopes in the past five years or so, independently of one another, and shared their recommendations of the technology with other colleagues through word of mouth. This means that some scholars are familiar with this technology, but many others, including some of the most prominent researchers in ancient manuscript studies, are not. This study thus aims to transform an oral tradition into a written document.

Before describing the circumstances under which my colleagues and I have used a digital microscope, it is important to address one preliminary matter: the possible pitfalls of utilizing such technologies. New tools of digitization have not only enabled manuscripts to be viewed upon the internet halfway around the world, but also, in the cases of technologies like digital microscopes and multi-spectral imaging, have allowed scholars to see features of the manuscripts that would be impossible otherwise. As a result of these developments, some scholars have emphasized the potential drawbacks of overreliance on digital images of manuscripts at the expense of direct observation of the physical manuscript itself. ${ }^{1}$

Three remarks about how the use of a digital microscope contributes to this conversation are pertinent. First, the digital microscope is in an interesting middle position between an in-person autopsy and the remote viewing of digital surrogates of a manuscript. Unlike a technician taking a photograph of a fragment in its entirety, a digital microscope is most effectively used by a scholar who is directly observing the manuscript, and is taking images of those portions of the text that he or she finds most difficult or problematic. Thus, it is much more "interactive" - at least for the initial observer - than simply examining from afar a digital surrogate whose producer may or may not have been particularly knowledgeable about or interested in the manuscript in question. Second, there is definitely the potential for overreliance upon the images produced by a digital microscope (to say nothing of other digital surrogates), since it can potentially produce "false positives," such as ink traces that are only

1 See especially Terras, Melissa M., "Artefacts and Errors: Acknowledging Issues of Representation in the Digital Imaging of Ancient Texts," in: Kodikologie und Paläographie im Digitale Zeitalter 2, Fischer, Franz, Fritze, Christiane, Vogeler, Georg, eds., Norderstedt: Books on Demand, 2010, $43-61$. 
shadows and the like. The in-person observer, thus, has a responsibility to ensure that what he or she is examining is really there, by taking multiple photographs in different types of light, at different angles, and from both sides of the fragment. Third, there is absolutely nothing that replaces having the actual physical manuscript present for observation with the naked eye, even if one is also utilizing a digital microscope at points during this process. In the case of the manuscript that the lead author has examined most extensively with a digital microscope, he returned to his home institution with several thousand images taken under the microscope - and yet, there were, perhaps inevitably, cases where he could not see the feature of the manuscript he wanted to with the photos.

The settings for this use of a digital microscope were the Sackler Library of Oxford University, the main repository for the Oxyrhynchus Papyri, and also Cambridge University Library, where several manuscripts from the Oxyrhynchus collection now reside. The microscope was used by the lead author and his colleague Geoffrey S. Smith, as well as by several of our graduate students at the University of Texas at Austin, two of whom are co-authors of this article. The digital microscope used was manufactured by Dino-Lite, and the model number is AD4113T-I2V. Its specifications include: a combination of LED, UV, and IR lights; a USB cable that allows images to be projected onto a computer screen so that the quality of the photos can be immediately analyzed; an adjustable magnification range of 20-200x; and a 1.3 Megapixel camera with $1280 \times 1024$ resolution. ${ }^{2}$

In this study, three specific papyri manuscripts will be discussed; two of the three fragments are probably apocryphal Christian texts, and the third definitely is. Brent Landau examines Papyrus Oxyrhynchus II 210, a possible apocryphal gospel fragment. Adeline Harrington examines Papyrus Oxyrhynchus LX 4009, whose identification as part of the Gospel of Peter has been debated among scholars. James C. Henriques examines Papyrus Oxyrhynchus LXV 4469, an amulet containing part of King Abgar's letter to Jesus. Unfortunately, it will not be possible to present in this article revised transcriptions of these three fragments. In the case of P.Oxy 210, a new transcription and thorough study will appear elsewhere; 3 in the case of the other two fragments, new transcriptions are planned, but more research needs to be undertaken prior to these being published.

2 Its suggested retail price is $€_{350-550}$ or $\$ 629.00$. The authors are immensely grateful to the Egypt Exploration Society, the Syndics of Cambridge University Library, and Dr. Ben Outhwaite of Cambridge University for their permission to use images taken with this microscope in the present study.

3 See note 8 below for publication information. 
P.Oxy. 210 consists of a single fragmentary leaf from a codex, currently housed at Cambridge University Library and measuring 17.4 by $9 \mathrm{~cm}$, dating perhaps to the third century. ${ }^{4}$ It is incomplete enough that its precise contents can only be guessed at; however, the verso almost certainly has Jesus speaking about good and bad trees and fruit, as well as stating that he is the "image" and "form" of God; it thus contains an intriguing blend of Synoptic, Johannine, and Pauline features. The recto mentions an angel several times, and although previous scholars have suggested that it is an infancy narrative, the other reconstructable words appear to make better sense as part of an apocalyptic or paranetic discourse, whether spoken by Jesus or someone else. Three particularly important editions of 210 have been published by pre-eminent papyrologists: Grenfell and Hunt in $1899,{ }^{5}$ C.H. Roberts in $1987,{ }^{6}$ and Stanley E. Porter in 2001. ${ }^{7}$ The editors have disagreed markedly about its transcription at a number of points. A new transcription and study of this enigmatic fragment by the lead author of this article has been published. ${ }^{8}$

Although the use of a digital microscope for examining P.Oxy. 210 has been beneficial in general, there are a number of places where a digital microscope has been invaluable in adjudicating between readings upon which previous editors disagreed. The digital microscope has also, on occasion, helped to point toward readings that no previous editors suggested. This presentation will not discuss every one of these instances, but will instead highlight several of the more striking and consequential examples. The instances will be presented sequentially, starting with the recto (in the direction of the fibers).

4 There do not seem to be any images of P.Oxy. 210 available online, though color plates can be found in: Wayment, Thomas A., The Text of the New Testament Apocrypha (10o-40o CE), New York: Bloomsbury, 2013, 402-403.

5 Grenfell, Bernard P., Hunt, Arthur S., "210. Early Christian Fragment," in: The Oxyrhynchus Papyri, Volume 2, London: Egypt Exploration Society, 1899, 9-10.

6 Roberts, Colin H., "An Early Christian Papyrus," in: Miscellània papirològica Ramon Roca-Puig, Janeras, Sebastià, ed., Barcelona: Fundació Salvador Vives Casajuana, 1987, 293-296.

7 Porter, Stanely E., "POxy II 210 as an Apocryphal Gospel and the Development of Egyptian Christianity," in: Atti del XXII Congresso internazionale dipapirologia: Firenze, 23-29 agosto 1998, Isabella Andorlini et al., eds., Florence: Instituto papirologico G. Vitelli, 2001, 1095-1108.

8 Landau, Brent C., "A Re-transcription and Analysis of a Possible Apocryphal Gospel Fragment, Papyrus Oxyrhynchus II 210, Utilizing a Digital Microscope," in: Ephemerides Theologicae Lovaniensis, 94/3 (2018): 427-80. At present, the most widely available transcription of the text appears in Ehrman, Bart D., Pleše, Zlatko, The Apocryphal Gospels: Texts and Translations, New York: Oxford University Press, 259-265; it basically reproduces the transcription of Roberts. A PDF of Grenfell and Hunt's editio princeps is available at: $<$ https://archive.org/details/ in.ernet.dli.2015.283588>, accessed on 10.04.19. 


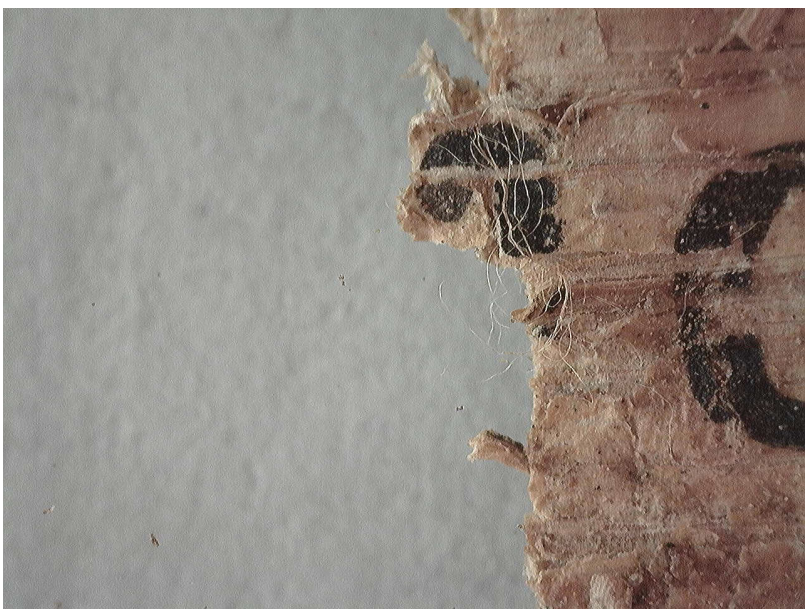

FIGURE 3.1

P.Oxy. 210. Possible omicron in line 3 , recto; (C)BRENTLANDAU

At recto line 3, all previous editors have read the first letter of the line as a rho, with or without an underdot. Since the next three letters can be easily read as $\sigma v$, this allowed C.H. Roberts to reconstruct the word as $x \dot{\alpha} \theta \alpha \rho \sigma \nu$ - quite a sensible reconstruction, since very few Greek words end with the sequence povv. However, with the digital microscope, it can be seen that the top of the oval in the first letter is unclosed (Figure 3.1).

The rhos of this scribe all have a closed, more circular top, and on at least two other occasions, the scribe has failed to close the circle of an omicron. Although certainty in this instance is difficult, I have chosen to read the first letter as an underdotted omicron. This yields the sequence orv, which is unfortunately far more common than pov but probably the correct reading. The fragmentary nature of this portion of the papyrus makes reconstruction impossible, but this is nevertheless an instance where the use of a digital microscope has provided an entirely new reading for a letter upon which all previous editors were in agreement.

Line 7 of the recto is very fragmentary, and the transcriptions of the three major editions have significant divergences. Grenfell and Hunt read it as

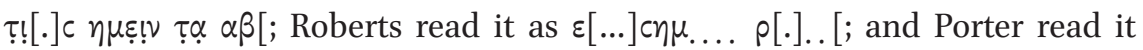
as ... $\varnothing \eta \mu .[ \pm 3 / 4] \ldots[$. The transcriptions are thus quite diverse, both in terms of which letters they regard as capable of being read and the identities of the letters that are extant. Yet the stakes for this line are quite high, since Roberts and then Porter reconstructed the line to render an infancy narrative context plausible, particularly when combined with the references to an angel in the two

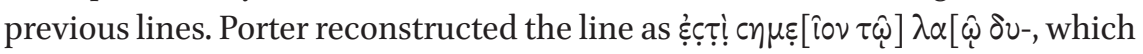
he interpreted to mean that the infant Jesus "is a sign for the people."

9 Porter, Stanley E., "POxy II 210 as an Apocryphal Gospel”, 1101-1102. 


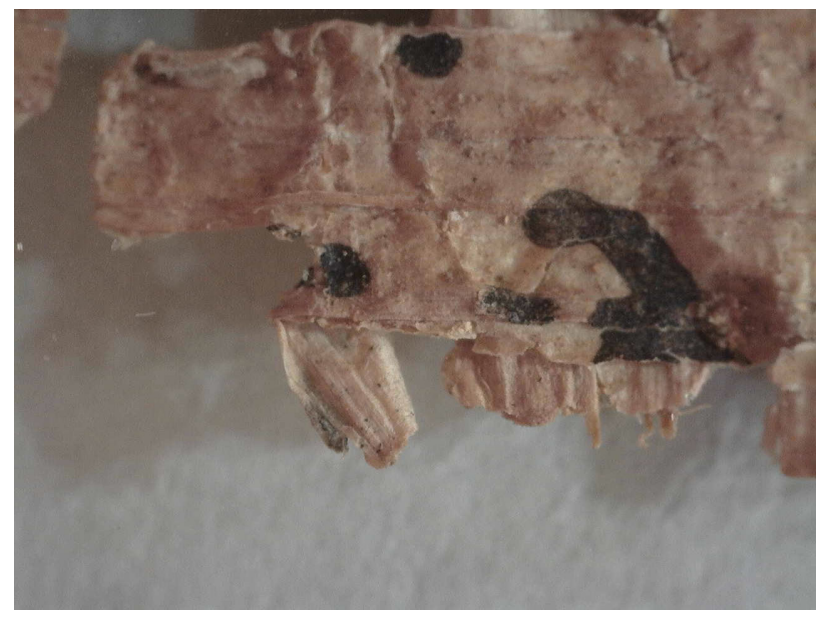

FIGURE 3.2

P.Oxy. 210. Part of tau in line 7 , recto, papyrus partially twisted; (C)BRENTLANDAU

My transcription has key differences from previous editions: $\tau\lfloor\propto \varphi \eta \eta \mu \omega \nu \tau . . \beta[$. For virtually every letter in this line, I relied on a combination of the digital microscope and an inventorying that I created of all the letter forms in 210. There were, however, two instances in which an extremely uncertain letter was confirmed by the digital microscope. For the fourth letter from the end of the line, the digital microscope reveals it to be a tau. There is only a tiny horizontal stroke visible on the recto, but the microscope shows that a fiber has been twisted around. When the same fiber is examined on the verso, we find more of the tau's crossbar, as well as the beginning of its vertical downstroke (see Figures 3.2 and 3.3 ).

The final letter of the line was read quite confidently by Grenfell and Hunt as a beta, but no subsequent editors adopted this reading. Although there are no other betas in the manuscript with which this letter can be compared, the digital microscope makes clear that beta is the correct reading. There is a loop at the top of the letter that led Roberts to read it as a rho, but the beginning of the bottom loop of the beta does indeed begin before the manuscript breaks off (Figure 3.4).

The two letters between the tau and the beta have distinctive top hooks that are only found in the scribe's alphas, deltas, and lambdas. Although I have marked these two letters in my transcription as underdots, the Greek is only intelligible if the letters are both alphas. It is quite plausible to read the sequence $\tau \alpha \alpha \beta$ as $\tau \dot{\alpha}$ 'A $\beta \alpha \alpha \dot{\alpha} \mu$ - that is, as "the things (perhaps $\tau \dot{\varepsilon} x \nu \alpha$, "children," similar to Matt 3:9/Luke 3:8, John 8:39, and Rom 9:7) belonging to Abraham." When we combine this potential reading with the two earlier references to an angel, a verb of command (- $\tau \alpha \xi \varepsilon$ in line 5$)$, and the infinitive of the verb "to

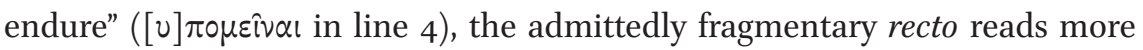




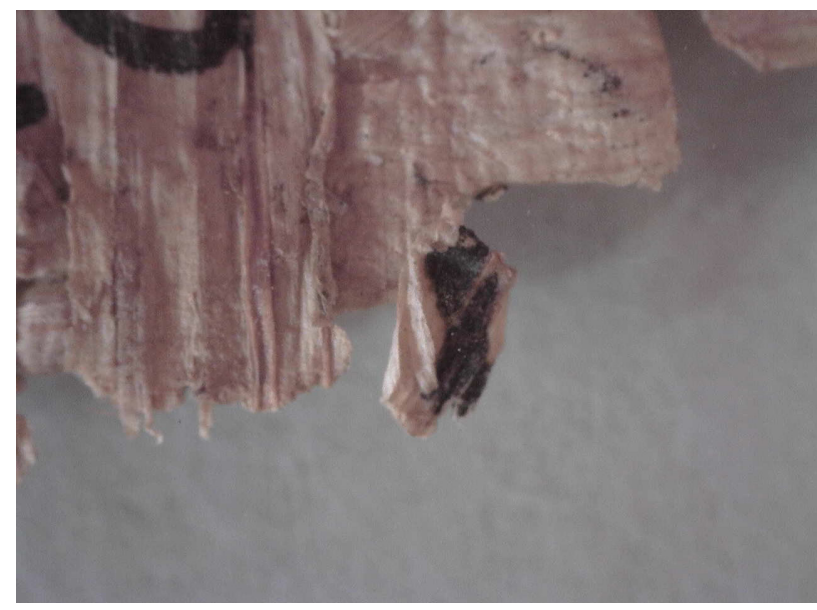

FIGURE 3.3

P.Oxy. 210. Remainder of tau in line 7 , recto, twisted onto verso side; (C) BRENTLANDAU

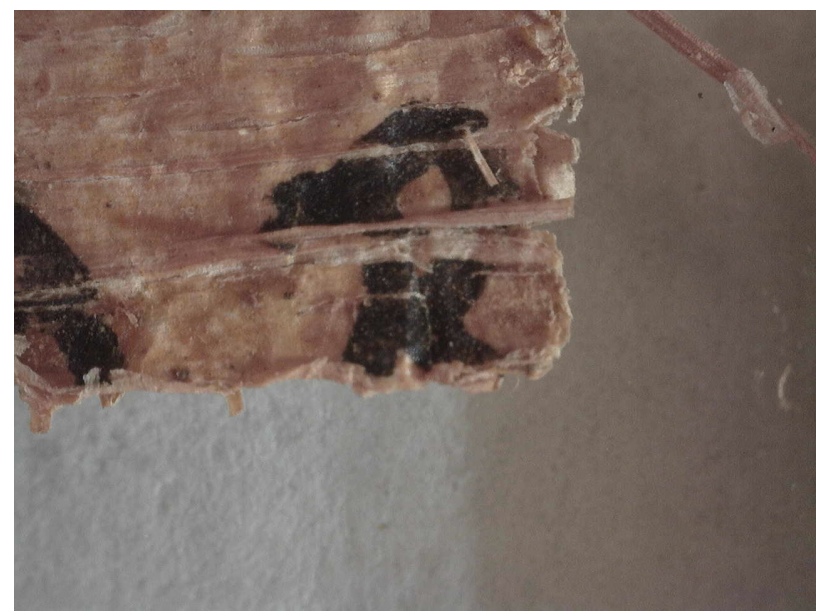

FIGURE 3.4

P.Oxy. 210. Beta in line 7, recto;

(C)BRENTLANDAU

like an apocalyptic or paranetical discourse given by an angel, and less like an infancy narrative.

If we move over to the verso side, the digital microscope provides several other insights. In the very fragmentary line 8 , all previous editors agree that all that can be seen is ] $\tau$ [. Yet not only is there a visible ink trace at the end of the line that merits an underdot, but even a letter before the tau is able to be read with some confidence. Visible to the naked eye is the curving bottom of a letter; the digital microscope reveals the faint trace of a curving top, and there is also a faint trace of a horizontal stroke extending from the middle of the letter (see Figure 3.5).

Therefore, I have read an underdotted epsilon before the tau. This line is so fragmentary that an underdotted epsilon does not provide much help in 


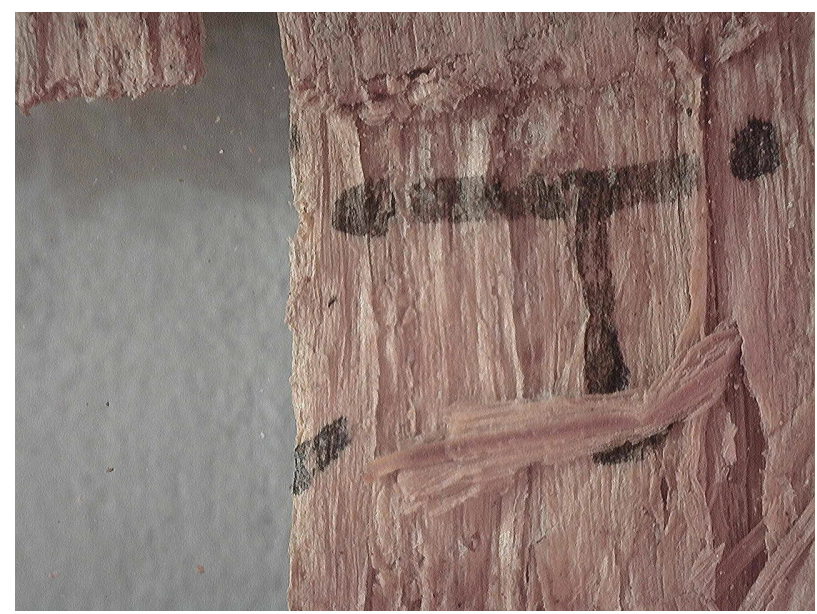

FIGURE 3.5

P.Oxy. 210. Possible remainder of epsilon in line 8, verso; (C)BRENTLANDAU

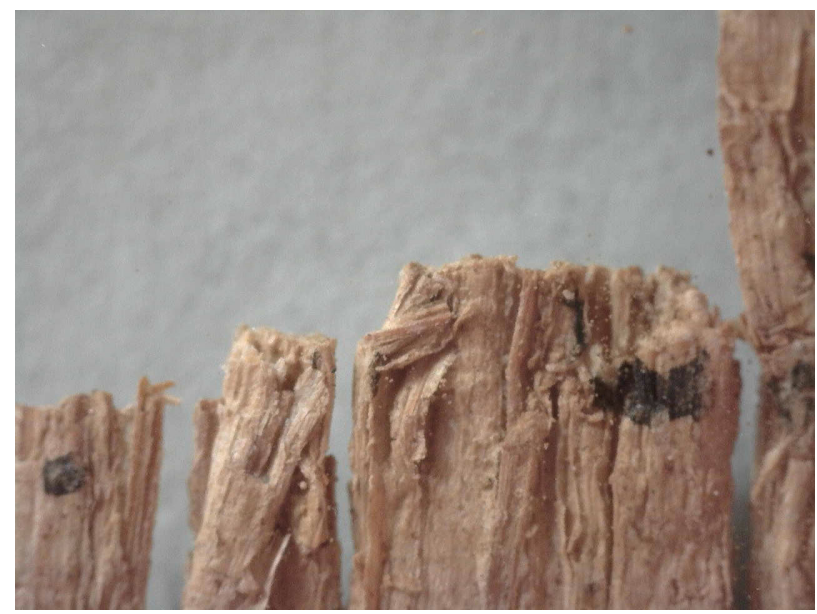

FIGURE 3.6

P.Oxy. 210. Possible remainder of $p i$ in line 9 , verso;

(C)BRENTLANDAU

deciphering it. Even so, this is an instance where the digital microscope has enabled the possible identification of an additional letter recorded by no other editors.

Line 9 of the verso is also quite damaged, but it seems possible to read a rather distinctive word in it, identified by no previous editors. After a tiny ink trace at the beginning of the line, the first letter is read by Grenfell and Hunt as an underdotted $p i$, by Porter as an underdot, and is strangely not recorded at all in Roberts's edition. Yet it is quite likely (though not certain) to be a pi. There is a bottom curve that is characteristic of the scribe's second leg of the pi, and where we would expect the first leg of the pi to be, the digital microscope reveals that several fibers have been folded over (see Figure 3.6). 


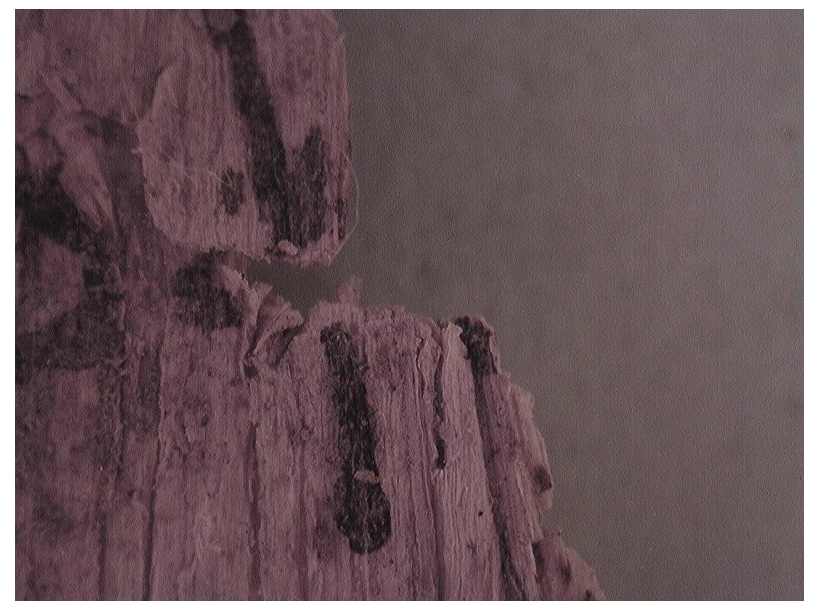

FIGURE 3.7

P.Oxy. 210. Remainder of phi in line 9, verso;

(C)BRENTLANDAU

Thus I read it in my edition as an underdotted $p i$, followed by a rho and an omicron, about which all editors are in agreement. Editors are again divided about the identity of the final letter: Grenfell and Hunt read it as an iota, Porter reads it as an underdotted phi. Porter recognized that there was a circle in the middle of the vertical stroke; it is possible to see this with the naked eye somewhat, but it is particularly clear with the digital microscope, so much so that I do not regard an underdot as necessary (see Figure 3.7).

Taken together, we have a reasonably secure sequence $\pi$ po $\varphi$; in the more than 200 instances of this sequence found in the NT, all but a few are the noun

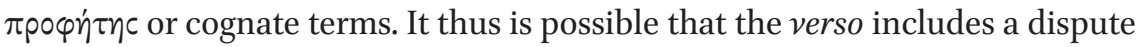
about whether or not Jesus is a prophet, or perhaps one in which Jesus is either citing a prophet or telling a story about one.

As a final example of the contributions of the digital microscope to the deciphering of 210, at line 25 of the verso, all editors have agreed on the sequence

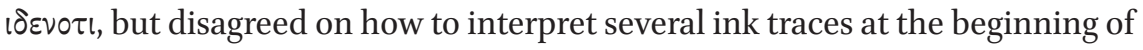
the line. Grenfell and Hunt and Porter regarded the ink traces above the iota as a diairesis marker (i.e., trema), while Roberts instead apparently read an underdotted epsilon before the iota, saying nothing about the presence of a diairesis. With the aid of the digital microscope, it is clear that there are two separate dots above the iota serving as a diairesis, but there is also a separate mark to the left of the iota (see Figure 3.8).

This mark is very high and appears to be the end of a horizontal stroke, which is presumably what Roberts read as an epsilon. The mark appears to be too high for an epsilon, however, and since line 26 has $1 \delta \varepsilon v$ as an iotacism for

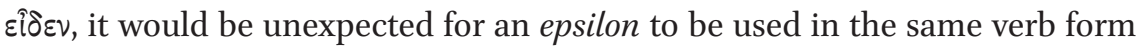
one line above. The height of the horizontal stroke, followed by a verb in the 


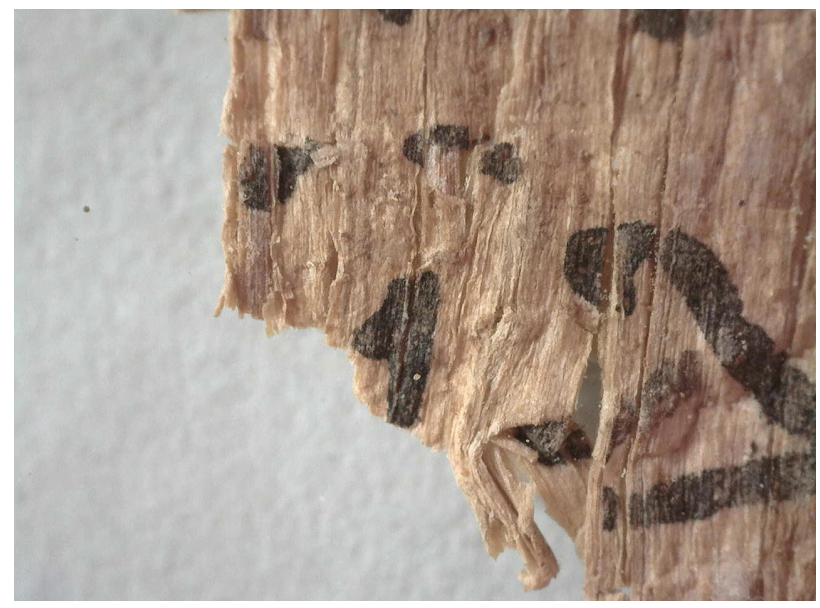

FIGURE 3.8

P.Oxy. 210. Dots of diairesis marker and possible remainder of nomen sacrum, line 25 , verso;

(C)BRENTLANDAU

third-person singular, suggests that it may be a supralinear stroke indicating a nomen sacrum - presumably the name Jesus (the nomen sacrum for Jesus is almost certainly present in verso line 13). Thus, my transcription of this line is:

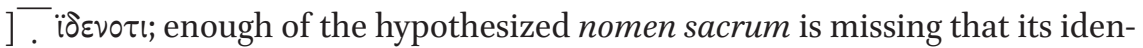
tity cannot be certain, thus I have underdotted it. Yet if I am correct in my transcription, this line would contain the phrase "Jesus saw that...," perhaps indicating that what we have here is a pronouncement story of some kind.

In concluding our discussion of the enigmatic fragment P.Oxy. 210, it is no exaggeration to say that the use of a digital microscope has been invaluable for creating a new and more accurate transcription of this text. The examples presented above are but a sampling of the instances in which the digital microscope either confirmed one possible reading among several or demonstrated the viability of a reading suggested by no previous editors.

\section{3}

\section{Papyrus Oxyrhynchus 4009}

P.Oxy. LX 4009 is a small fragment $(2.9$ by $9 \mathrm{~cm})$ dating to the second or early third century that has received a significant amount of attention over the past two decades. ${ }^{10}$ In 1993, Dieter Lührmann identified the text as a possible fragment of the Gospel of Peter. ${ }^{11}$ In the following year, he and Peter Parsons published a transcription and reconstruction of the text and connected one side of

10 Images of P.Oxy. 4009 appear on the Oxyrhynchus Papyri website. The following shortened link directs to the page containing images of the fragment: <http://tinyurl.com/ poxy40og>, accessed on February 28, 2018.

11 Lührmann, Dieter, "POx 40og: Ein neues Fragment des Petrusevangeliums," NovT 35, 1993, 390-410. 
the fragment with passages parallel in Matt 10:16, Luke 10:3, Gospel of Thomas 39, and 2 Clem 5.2-4 about Jesus sending his disciples out as sheep among wolves. ${ }^{12}$ Lührmann's identification of the text as a section of Gos. Pet. has been further supported by Matti Myllykoski. In a recent article, Myllykoski goes one beyond Lührmann's work by providing a full reconstruction for the less intelligible side of the fragment, which he says narrates the pericope of the sinful woman in Luke 7:36-50 in agreement with the Western text type..$^{13}$

Recently, however, Lührmann's reconstruction of the text and its connection to Gos. Pet. has been criticized by Paul Foster. ${ }^{14}$ In Foster's opinion, Lührmann's reconstruction contains two major weaknesses. First, Foster notes that 4009 does not bear any resemblance to the other two possible fragments of Gos. Pet. that we have (P.Oxy. 2949 and the Akhmîm codex).$^{15}$ Second, he is skeptical of Lührmann's reconstruction; both sides of the papyrus, Foster says, are too fragmentary to be certain of any direct connection to another text, much less an early apocryphal gospel of which we have no verified copy.

With the use of a digital microscope in the Sackler Papyrology Room at Oxford, the author was able to take a closer look at 4009 and produce a revised transcription of the text. After isolating and capturing high-resolution images of each letter within the manuscript, the author was able to identify several questionable letters in the body of the text with more certainty. Moreover, by comparing the fragmentary letters along the edges of the papyrus to the more definitive and visible letter forms in the body, I was able to determine the most plausible letters in the sequence. At a few key points these letters do not match the previous reconstructions by Lührmann/Parsons and Myllykoski.

The extant text of the fragment is fairly legible. The hand is neat, and thus scholars generally agree about the identity of most letters along the center of the fragment. It is the letters on the edges of the fragment that deserve further

Lührmann, Dieter, Parsons, Peter J., "4009. Gospel of Peter?" in: The Oxyrhynchus Papyri, vol. 6o, London: Egypt Exploration Society, 1994, 1-5. The most widely available transcription is in Ehrman and Pleše, Apocryphal Gospels, 289-293.

Myllykoski, Matti, "The Sinful Woman in the Gospel of Peter: Reconstructing the Other Side of P.Oxy. 4009," NTS 55, 2009, 105-115. See also Myllykoski's follow-up article on P.Oxy. 4009, which provides an interpretation of his own reconstruction, "Tears of Repentance or Tears of Gratitude? P.Oxy. 4009, the Gospel of Peter and the Western Text of Luke 7.4549," NTS 55, 2009, 380-389.

14 Foster, Paul, "Are There Any Early Fragments of the So-Called Gospel of Peter?" NTS 52, 2006, 1-27.

While Kraus and Nicklas are not as critical of Lührmann's reconstruction as Foster is, they too take issue with the lack of connection between this text and the Akhmîm codex. See Kraus, Thomas J., Nicklas, Tobias, Das Petrusevangelium and die Petrusapokalypse: Die Griechischen Fragmente mit deutscher und englisher Übersetzung, Berlin: W. de Gruyter, 2004, 59-64. 


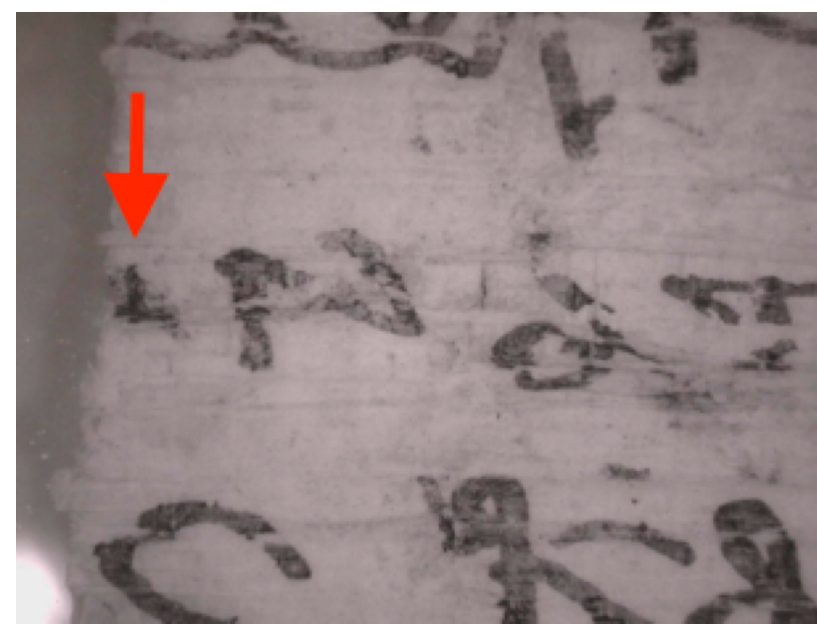

FIGURE 3.9

P.Oxy. 4009. Remainder of tailed letter preceding a $n u$ in line 16 , recto;

(C)ADELINEHARRINGTON

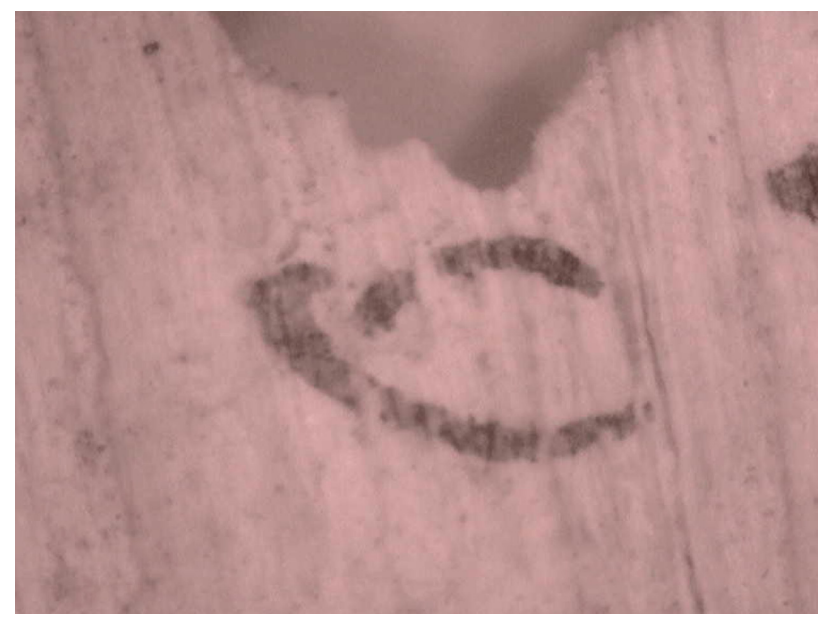

FIGURE 3.10

P.Oxy. 4009. Omicron in

line 4, verso;

(C)ADELINEHARRINGTON

consideration. There have been a few speculative attempts at these fragmentary letters in earlier editions, but for the most part, they have been left untouched by researchers. It is these fragmentary letters to which I paid the most attention in my autopsy of the manuscript. I do not present a full transcription here, but instead some select readings of the text ascertained with the infrared lighting mode of the digital microscope.

We begin with several instances in which the digital microscope helps to determine that previous editors transcribed letters incorrectly. At the beginning of line 16 on the recto, there is a trace of a letter with a visible tail leading out of it (Figure 3.9).

I have transcribed it as an underdotted alpha, but it could be one of several other letters written with a final tail. This tailed letter, however, Lührmann's 

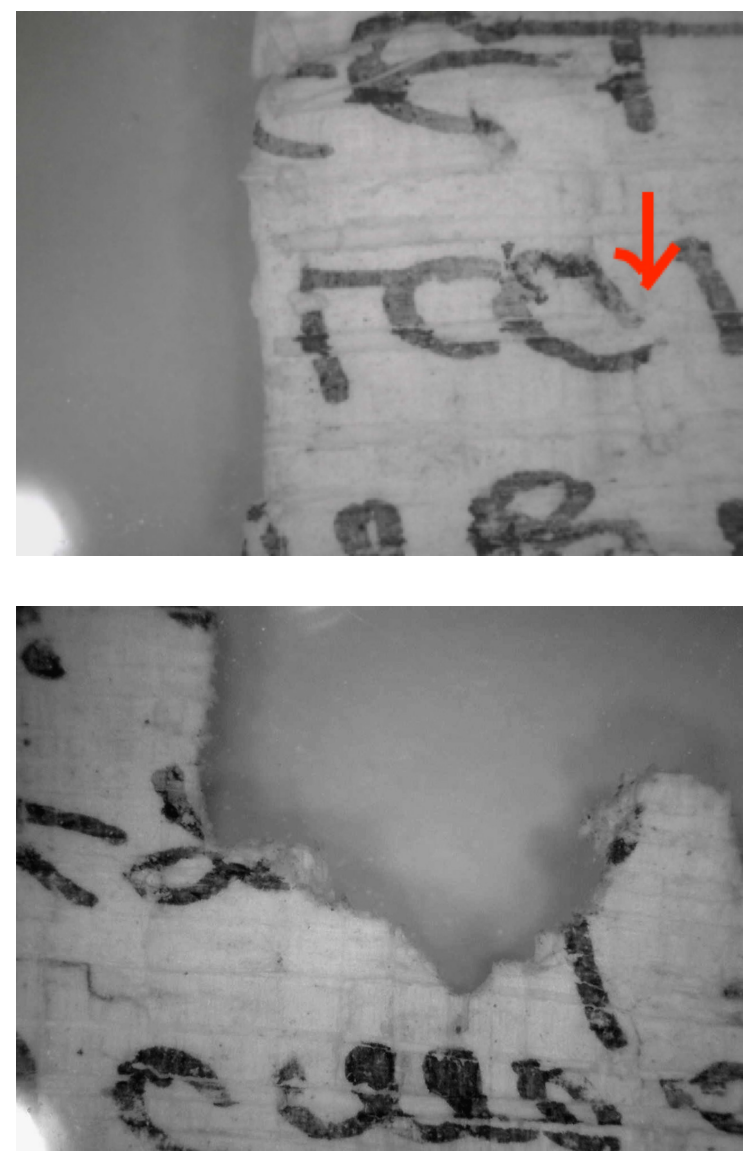

FIGURE 3.11

P.Oxy. 4009. Similar omicron in line 16 , recto;

(C)ADELINEHARRINGTON
FIGURE 3.12

P.Oxy. 4009. Possible remainder of phi in line 3 , recto;

(CADELINEHARRINGTON

transcription of an omega very improbable. The omegas in this manuscript are looped and closed (cf. recto line 8).

As a second example, the letter that begins line 4 of the verso is odd in that it appears, upon first glance, to be formed by two round strokes. Given the opening apparent on the right side of the curved letter, Lührmann read it as an underdotted sigma and Myllykoski as a sigma with no underdot. Upon closer inspection with the microscope, however, it appears that a single stroke formed the closed loop of an omicron, although partially faded (Figure 3.10). This is not unlike the wear on the omicron we also see in recto line 14 (Figure 3.11).

The author's in-person autopsy with the digital microscope also allowed her to identify several letters that had only been transcribed as underdots by previous editors. At the end of line 3 of the recto, Lührmann records an underdot, indicating that traces of ink are present but that not enough of the letter remains to discern its identity. Yet under magnification it is possible to determine the 

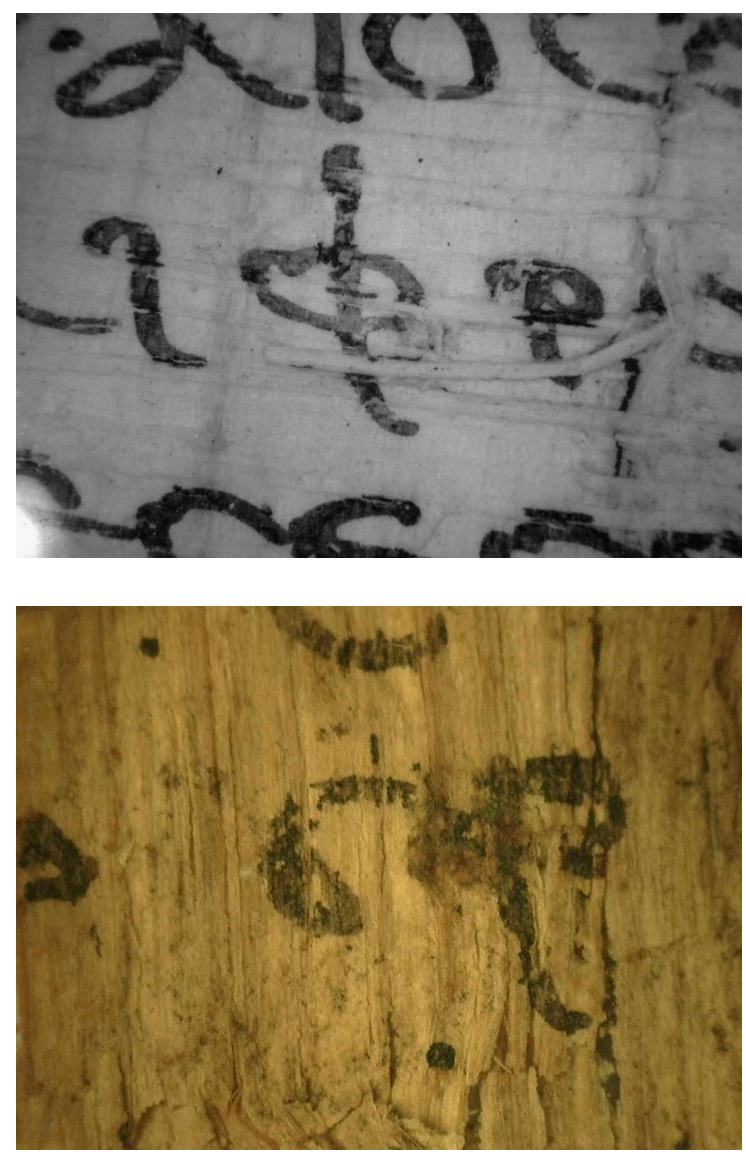

FIGURE 3.13

P.Oxy. 4009. Phi and rho written next to each other in line 6, recto; (C)ADELINEHARRINGTON
FIGURE 3.14

P.Oxy. 4009. Previously untranscribed upsilon and rho in line 19, verso;

(C)ADELINEHARRINGTON

letter with a reasonable degree of confidence. With a partial loop and a vertical line it has the potential to be read as a rho. This letter form, however, is more consistent with the other phis within the manuscript than with the rhos (Figure 3.12).

This is especially apparent when phi and rho are viewed next to each other (see Figure 3.13). With the exception of some iotas (cf. recto line 14), phis dip down further than any extant letter in 4009 (cf. verso line 8). Thus, this letter is more likely to be a phi than a rho, although its identity cannot be determined with absolute certainty.

The final lines of the verso are faded and damaged, and are thus particularly challenging to read. With the aid of the digital microscope, however, several letters previously transcribed only as underdots can now be read. In line 19 of the verso, the high-resolution images clearly capture an upsilon gliding into a rho (Figure 3.14). 


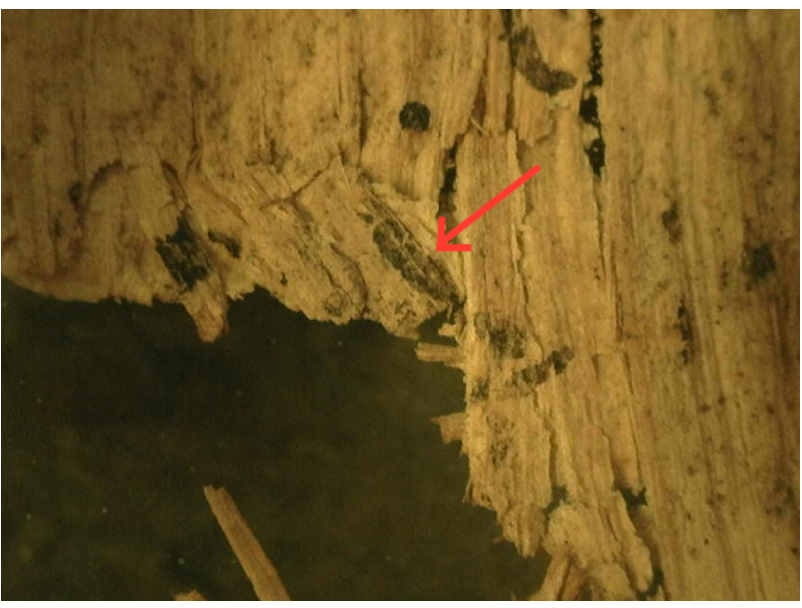

FIGURE 3.15

P.Oxy. 4009. Looped alpha visible in line 20, verso;

(C)ADELINEHARRINGTON

The final line of the text (line 20, verso) is especially deteriorated. With an enhanced zoom, however, the top loop of an alpha is visible here (Figure 3.15). This looped alpha is consistent with other alphas in the manuscript (cf. especially recto lines 16 and 17 ).

Although a full transcription has not been offered here, the use of a digital microscope has made it clear that a more accurate transcription and more plausible reconstruction of 4009 is needed. Whether this text is indeed part of Gos. Pet. will likely not be resolved anytime soon due to its fragmentary condition, but a new examination may help to determine the contents of this enigmatic apocryphon.

P.Oxy. LXV 4469 is a copy of the letter of Abgar, King of Edessa, to Jesus, in the form of an amulet. ${ }^{16}$ Whereas the "original" letter requests that Jesus come to Edessa to heal Abgar, 4469 replaces Abgar with the name of the amulet's petitioner, Epimachus. ${ }^{17}$ The amulet is $5.3 \mathrm{~cm}$ wide by $15 \mathrm{~cm}$ long, with several

16 Images of P.Oxy. 4469 appear on the Oxyrhynchus Papyri website. The following shortened link directs to the page containing images of the fragment: <http://tinyurl.com/ poxy4469> (accessed on February 28, 2018).

For the Abgar legend, see Doctrina Addai, De Imagine Edessena = Die Abgarlegende, das Christusbild von Edessa, Illert, Martin, ed., Turnhout: Brepols, 2007. For more on the use of the Jesus-Abgar correspondence in amulets, see von Dobschütz, Ernst, "Der Briefwechsel Zwischen Abgar und Jesus," ZWTh 43, 1900, 422-487; Youtie, Herbert C., "A Gothenburg Papyrus and the Letter to Abgar," HTR 23, 1930, 299-302; Youtie, Herbert C., "Gothenburg 
lacunae on the left side. The text is written along the fibers, with each line of text running at an ever-increasing downward diagonal slant to the right. The reverse side is blank. Mostly written in Greek, the text switches to Coptic at line 21, and continues for four lines before returning to Greek. Franco Maltomini, who first published the fragment, dated it to the late fifth century CE, based on paleographic evidence. ${ }^{18}$ In addition to the slant of the lines, the script itself is small and uneven, making this a rather difficult text to read.

Re-examining this text under the lens of a digital microscope was both a blessing and a curse; a blessing because the high resolution of the camera and the ability to manipulate digitally the images provided far greater ease in recognizing boundaries between letters that had blended together, viewing ink traces around lacunae, and examining less legible areas where the scribe had run out of ink. These very improvements, however, were also a curse in that they only provided a wider range of possibilities for deciphering the scribe's poor handwriting. In other words, being able to adjust the contrast on a blob of ink to make it more visible and defined does not change the fact that it is still a blob of ink, and is therefore inherently ambiguous in its identity.

The most useful feature of the microscope was the infrared mode, which helped the ink to stand out on the page in a way that a simple high contrast black-and-white image could not. This tool clarified some of the ambiguities that apparently plagued Maltomini in his transcription and translation of this frustrating fragment. The most notable observation, missed by Maltomini, is that the scribe inconsistently switched between two forms of the letter eta. The first form resembles a backwards Roman capital "N," with the top of the upward diagonal stroke and the second vertical meeting at an angle as high as the

Papyrus 21 and the Coptic Version of the Letter to Abgar," HTR 24, 1931, 61-65; Peppermüller, Rolf, "Griechische Papyrusfragmente der Doctrina Addai," VC 25,1971, 289-301; Salomons, Robert P., "The Correspondence between Abgar and Jesus: A re-edition of a Bodleian Papyrus," in: Land of Dreams: Greek and Latin Studies in Honour of A.H.M. Kessels, Lardinois, Andre P.M.H., van der Poel, Marc G.M., Hunink, Vincent J.C., eds., Leiden: Brill, 2006, 299-307; Caseau, Béatrice, "La lettre de Jésus à Abgar d'Édesse: appropriations et transformations," in: Remanier, métaphraser, Fonctions et techniques de la réécriture dans le monde byzantin, Marjanović-Dušanić, Smilja, ed., Belgrade: Faculté de Philosophie, Université de Belgrade, 2011, 13-43; Sanzo, Joseph E., "Brit. Lib. Or. 4919(2): An Unpublished Coptic Amulet in the British Library," ZPE 183, 2012, 98-100; Emmenegger, Gregor, "Der Abgarbrief und seine Verwendung in koptischen Amuletten," in: Das Christusbild, Zu Herkunft und Entwicklung in Ost und West, Das östliche Christentum, Dietz, Karlheinz, Hannick, Christian, Lutzka, Carolina, Maier, Elisabeth, eds., OeCh 62, Würzburg, Echter, 2016, 121-134; Given, J. Gregory, "Utility and Variance in Late Antique Witnesses to the Abgar-Jesus Correspondence," Archiv für Religionsgeschichte 17, 2016, 187-222. 


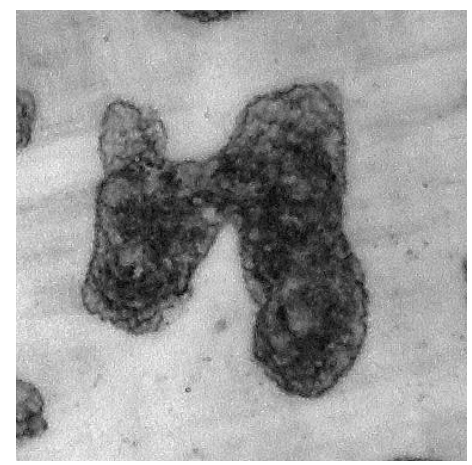

FIGURE 3.16

P.Oxy. 4469. First form of eta, resembling a backwards Roman capital "N";

(CJAMESHENRIQUES

FIGURE 3.17

P.Oxy. 4469. Second form of eta, resembling a lower-case Roman " $h$ ";

CJAMESHENRIQUES

first vertical stroke, while the bottom of the second vertical stroke drops below the line (see Figure 3.16).

The second form more closely resembles a lower-case Roman letter "h," beginning with a high vertical stroke which then curves upward at a narrow angle, but rises only about half as high as the first vertical stroke before curving downward again at a wider angle, often terminating at a point higher than the bottom of first vertical stroke (Figure 3.17).

While the scribe alternates inconsistently between both forms throughout the Greek text, he uses the latter exclusively when writing in Coptic. Furthermore, given the gradually increasing slant of each line, the scribe had a tendency to sometimes (but not always) slant the letters in relation to the gradient of the line, thus sometimes making the latter form of eta look like his upsilon, which in his hand resembles the Roman letter "v," and vice-versa.

This confusion is nowhere more evident than in line 19, where Maltomini has transliterated the text as $\sigma x \eta \lambda \lambda \hat{\eta} \nu \alpha \iota \varsigma$, regarding it as a gross misspelling of $\sigma x \cup \lambda \hat{\eta} \nu \alpha$ ( "to disturb"). Yet closer inspection has revealed that first eta to actually be an upsilon, making the word indeed $\sigma x v \lambda \hat{\eta} \nu \alpha \iota$ (which the scribe misspelled as $\sigma x \cup \lambda \hat{\eta} \nu \alpha \iota \varsigma)$. 


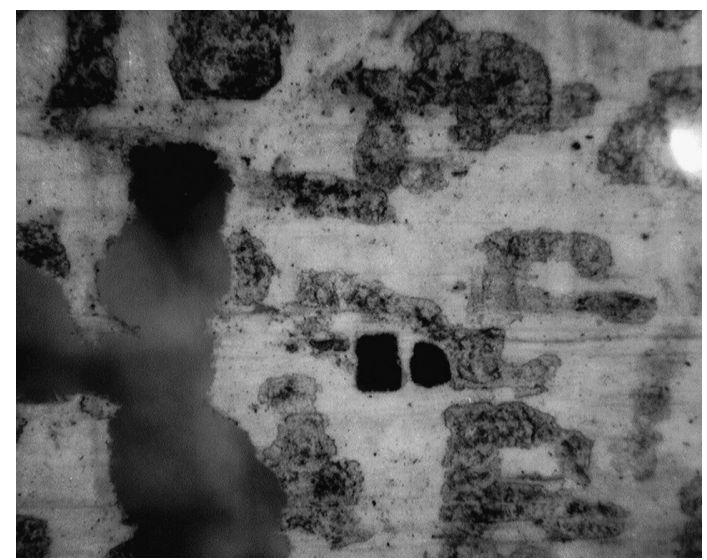

FIGURE 3.18

P.Oxy. 4469. Upsilon or omicron incorrectly transcribed as theta in line 17;

CJAMESHENRIQUES

$\sum \varkappa v \lambda \hat{\eta} v \alpha \mathrm{l}$ is in fact the form presented in the version of the Letter of Abgar to Jesus preserved by Eusebius in his Ecclestiastical History (1.13).

Closer examination under the digital microscope also suggested a corrected

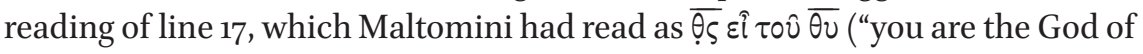
God"), which he noted was an error on the part of the scribe, who likely in-

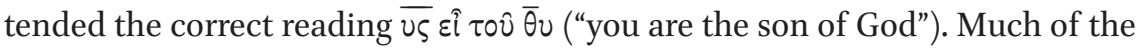
first half of the line is fragmentary, but close inspection reveals traces of ink around the lacunae that should likely alter Maltomini's reading. At the very least, the letter that Maltomini had identified as a theta cannot be one, since the scribe's thetas have a crossbar that extends outside of the central part of the letter, something that this fragmentary letter definitely lacks (Figure 3.18).

The identity of the fragmentary letter is not entirely clear: it could be an upsilon, in which case the scribe did indeed write the appropriate nomen sacrum of $\bar{v}$. But it is also possible that it is an omicron, which would suggest that the scribe spelled out the full viós rather than the abbreviated while curiously still retaining the superlinear stroke that denotes nomina sacra.

Although Maltomini's transcription of 4469 in general was excellent, the digital microscope has nevertheless clarified some of the most difficult portions of this very challenging fragment.

\section{5}

\section{Conclusion}

This study has demonstrated how the transcription of three fragmentary early Christian papyri can be corrected and refined through the use of a digital microscope, particularly one having an infrared lighting mode. There are, of course, limitations to the applications of this technology; some letters will still 
remain stubbornly illegible even under high-resolution magnification and infrared lighting. Even so, the number of early Christian and other papyri, both edited and unedited, that can benefit from editors including digital microscopes in their toolkits is truly staggering.

\section{References}

Brent C. Landau, "A Re-transcription and Analysis of a Possible Apocryphal Gospel Fragment, Papyrus Oxyrhynchus II 210, Utilizing a Digital Microscope," Ephemerides Theologicae Lovanienses 94/3 (2018): 427-80.

Caseau, Béatrice, "La lettre de Jésus à Abgar d'Édesse: appropriations et transformations," in: Remanier, métaphraser, Fonctions et techniques de la réécriture dans le monde byzantin, Marjanović-Dušanić, Smilja, ed., Belgrade: Faculté de Philosophie, Université de Belgrade, 2011, 13-43.

Doctrina Addai, De Imagine Edessena = Die Abgarlegende, das Christusbild von Edessa, Illert, Martin, ed., Turnhout: Brepols, 2007.

Ehrman, Bart D., Pleše, Zlatko, The Apocryphal Gospels: Texts and Translations, New York: Oxford University Press, 259-265.

Emmenegger, Gregor, "Der Abgarbrief und seine Verwendung in koptischen Amuletten," in: Das Christusbild, Zu Herkunft und Entwicklung in Ost und West, Das östliche Christentum, Dietz, Karlheinz, Hannick, Christian, Lutzka, Carolina, Maier, Elisabeth, eds., OeCh 62, Würzburg, Echter, 2016.

Foster, Paul, "Are There Any Early Fragments of the So-Called Gospel of Peter?" NTS 52, 2006, 1-27.

Given, J. Gregory, "Utility and Variance in Late Antique Witnesses to the Abgar-Jesus Correspondence," Archiv für Religionsgeschichte 17, 2016, 187-222.

Grenfell, Bernard P., Hunt, Arthur S., “210. Early Christian Fragment," in: The Oxyrhynchus Papyri, Volume 2, London: Egypt Exploration Society, 1899, 9-10.

Kraus, Thomas J., Nicklas, Tobias, Das Petrusevangelium and die Petrusapokalypse: Die Griechischen Fragmente mit deutscher und englisher Übersetzung, Berlin:W. de Gruyter, 2004, 59-64.

Landau, Brent C., "A Re-transcription and Analysis of a Possible Apocryphal Gospel Fragment, Papyrus Oxyrhynchus II 210, Utilizing a Digital Microscope," in: Ephemerides Theologicae Lovaniensis, forthcoming.

Lührmann, Dieter, "POx 40og: Ein neues Fragment des Petrusevangeliums," NovT 35, 1993, 390-410.

Lührmann, Dieter, Parsons, Peter J., “4009. Gospel of Peter?” in: The Oxyrhynchus Papyri, vol. 6o, London: Egypt Exploration Society, 1994, 1-5. 
Maltomini, Franco, "4469. Letter of Abgar to Jesus (Amulet)." The Oxyrhynchus Papyri, vol. 65, London: Egypt Exploration Society, 1998, 122-129.

Myllykoski, Matti, "Tears of Repentance or Tears of Gratitude? P.Oxy. 4009, the Gospel of Peter and the Western Text of Luke 7.45-49," NTS 55, 2009, 380-389.

Myllykoski, Matti, "The Sinful Woman in the Gospel of Peter: Reconstructing the Other Side of P.Oxy. 4009," NTS 55, 2009, 105-115.

Peppermüller, Rolf, "Griechische Papyrusfragmente der Doctrina Addai," VC 25,1971, 289-301.

Porter, Stanley E., "POxy II 210 as an Apocryphal Gospel and the Development of Egyptian Christianity," in: Atti del XXII Congresso internazionale di papirologia: Firenze, 23-29 agosto 1998, Isabella Andorlini et al., eds., Florence: Instituto papirologico G. Vitelli, 2001, 1095-1108.

Roberts, Colin H., "An Early Christian Papyrus," in: Miscellània papirològica Ramon Roca-Puig, Janeras, Sebastià, ed., Barcelona: Fundació Salvador Vives Casajuana, 1987, 293-296.

Salomons, Robert P., "The Correspondence between Abgar and Jesus: A re-edition of a Bodleian Papyrus," in: Land of Dreams: Greek and Latin Studies in Honour of A.H.M. Kessels, Lardinois, Andre P.M.H., Van der Poel, Marc G.M., Hunink, Vincent J.C., eds., Leiden: Brill, 2006, 299-307.

Sanzo, Joseph E., "Brit. Lib. Or. 4919(2): An Unpublished Coptic Amulet in the British Library," ZPE 183, 2012, 98-100.

Terras, Melissa, "Artefacts and Errors: Acknowledging Issues of Representation in the Digital Imaging of Ancient Texts," in: Kodikologie und Paläographie im Digitale Zeitalter 2, Fischer, Franz, Fritze, Christiane, Vogeler, Georg, eds., Norderstedt: Books on Demand, 2010, 43-61.

Von Dobschütz, Ernst, "Der Briefwechsel Zwischen Abgar und Jesus," ZWTh 43, 1900, 422-487.

Wayment, Thomas A., The Text of the New Testament Apocrypha (100-40o CE), New York: Bloomsbury, 2013, 402-403.

Youtie, Herbert C., "A Gothenburg Papyrus and the Letter to Abgar," HTR 23, 1930, 299-302.

Youtie, Herbert C., "Gothenburg Papyrus 21 and the Coptic Version of the Letter to Abgar," HTR 24, 1931, 61-65. 